\title{
MONITORING BABY INCUBATOR SENTRAL DENGAN KOMUNIKASI WIRELESS
}

\author{
Ary Sulistyo Utomo \\ Teknik Elektro Medik, Akademi Teknik Elektro Medik \\ Email: ary.utomo@gmail.com \\ Antonius Bagus Satrya \\ Teknik Elektro Medik, Akademi Teknik Elektro Medik \\ Yandri Tapparan \\ Teknik Elektro Medik, Akademi Teknik Elektro Medik
}

\begin{abstract}
ABSTRAK
Baby Incubator adalah suatu alat yang digunakan untuk menghangatkan bayi yang baru lahir dan sering digunakan pada bayi yang lahir secara premature. Baby Incubator ini juga berfungsi menjaga kehangatan, kelembaban tubuh bayi serta dapat mencegah terjadinya infeksi pernapasan pada bayi dan untuk mengisolasi bayi yang baru lahir terutama bayi yang lahir secara premature. Dengan kondisi tersebut diperlukan pengamatan atau monitoring terhadap bayi yang berada di baby incubator. Pembuatan baby incubator dengan sistem monitoring sentral ini digunakan untuk pemantauan kondisi lingkungan yang terdapat di ruang incubator. Baby Incubator ini terdiri dari rangkaian arduino nano, rangkaian pengendali heater dan wireless serial dengan modul kyl 1020. Prinsip kerja pemanasan menggunakan heater, yang dapat dikendalikan sudut penyalaan dari heater tersebut. Pembuatan aplikasi monitoring suhu menggunakan Microsoft Visual Studio. Hasil pengamatan disimpan pada database menggunakan microsoft acces. Dari hasil percobaan yang dilakukan jarak yang dapat dicapai untuk pengiriman data dalam kondisi line of sight (LOS) adalah 0-220m sedangkan untuk Non-Line of sight (NLOS) adalah $180 \mathrm{~m}$. Pengujian suhu ruang baby incubator menggunakan termometer sebagai perbandingan dengan nilai suhu yang dibaca pada alat. Dari pengukuran diperoleh tingkat perbedaan $0 \%$ pada suhu $30^{\circ} \mathrm{C}$ dan $2,8 \%$ pada suhu $37^{\circ} \mathrm{C}$.
\end{abstract}

Kata kunci: baby incubator, sistem monitoring sentral, microsoft visual studio, arduino.

\begin{abstract}
Baby Incubator is anotherapy used for newborns and premature babies. Baby Incubator also helps maintain the baby's warmth, moisture, and also can prevent infections in premature babies and newborns. Under these conditions it is necessary to observe or monitor the infants in the infant incubator. Make infant incubators with centralized system monitoring for the environment in the incubator room. This Baby Incubator consists of a series of arduino nano, series of wireless heater and serial controls with kyl module 1020. The working principle of heating using a heater, which can be used for heating. Create a temperature monitoring app using Microsoft Visual Studio. Observation results are stored in the database using microsoft acces. From the experimental results the distance that can be achieved for data transmission in line of sight condition (LOS) is 0-220m while for Non-Line of sight (NLOS) is 180m. The room temperature test of the infant incubator uses a thermometer in comparison with the temperature value read on the tool. From measurement level $0 \%$ at temperature $30^{\circ} \mathrm{C}$ and $2.8 \%$ at $37^{\circ} \mathrm{C}$.
\end{abstract}

Keywords: baby incubator, central monitoring system, microsoft visual studio, arduino.

\section{PENDAHULUAN}

Bayi prematur adalah bayi yang lahir dengan usia kehamilan kurang dari 37 minggu dan dengan berat kurang dari 2500 gram. Sebagian besar organ tubuhnya juga belum berfungsi dengan baik, karena kelahirannya masih dini. Maka dari itu, perlu diberikan perawatan khusus. Diantaranya ada penyesuaian suhu, kelembaban dan kebutuhan oksigen yang sesuai dengan kondisi dalam rahim ibu. Untuk itu perlu adanya Baby Incubator. Baby Incubator adalah suatu alat yang digunakan perawatan untuk bayi premature. Baby Incubator ini juga berfungsi menjaga kehangatan dan kelembaban tubuh bayi, mencegah terjadinya infeksi pernapasan pada bayi dan untuk mengisolasi bayi yang baru lahir atau bayi prematur. Maka dari itu alat Baby Incubator ini sangat diperlukan di rumah sakit sebagai upaya mengurangi angka 
kematian bayi khususnya yang lahir premature. Berdasarkan observasi yang dilakukan penulis di berapa rumah sakit di semarang, tenaga medis dalam hal ini perawat mengalami kendala dalam kinerjanya memonitoring tiap Baby Incubator. Dimana perawat harus selalu memonitoring satu-persatu incubator yang menyebabkan efisiensi pelayanan rumah sakit menjadi sangat terganggu.

Penelitan sebelumnya yang dilakukan oleh Christian F Ginting dkk berasal dari Universitas Sumatera Utara melakukan Perancangan inkubator bayi dengan pengaturan suhu dan kelembaban berbasis mikrokontroller Atmega8535 [1], Syahrul Berasal dari Unikom Bandung pada tahun 2012 melakukan pengembangan inkubator bayi dengan sistem pemantaun remote[2]. Roni Wijaya, F dkk berasal dari Universitas Kristen Satya Wacana pada tahun 2013 melakukan penelitian inkubator bayi berbasis mikrokontroller dilengkapi sistem telemetri melalui jaringan RS 485 [3],

Apriyadi pada tahun 2012 melakukan penelitian miniatur pemantau suhu inkubator bayi berbasis mikrokontroler atmega 8535 dan jaringan nirkabel [4], Noor Yulita Dwi Setyaningsih dkk berasal dari Universitas Muria Kudus melakukan kendali suhu inkubator bayi menggunaka PID [5].

Pada penelitian ini menggunakan rangkaian arduino nano, rangkaian pengendali heater dengan prinsip pengontrolan sudut penyalaan heater sehingga perubahan suhu dapat diharapkan lebih stabil, wireless serial dengan modul kyl 1020 digunakan sebagai interface antara baby incubator dengan komputer dan membuat aplikasi monitoring menggunakan Microsoft Visual Studio 2013. Pengaturan dan monitoring suhu dapat diatur melalui komputer. Hasil monitoring suhu dapat tersimpan di database. Database yang digunakan yaitu microsoft access.

\section{METODOLOGI PENELITIAN}

Pada metodologi penelitian yaitu membuat perangkat keras dan perangkat lunak. Rangkaian perangkat keras yaitu rangkaian pengendali heater, sensor suhu dan kelembaban, dan rangkaian display. Untuk perangkat lunak yaitu membuat aplikasi menggunakan microsoft visual studio 2013 dan database microsoft access. Diagram blok sistem ditampilkan pada Gambar 1. Diagram Blok Sistem dibawah ini.

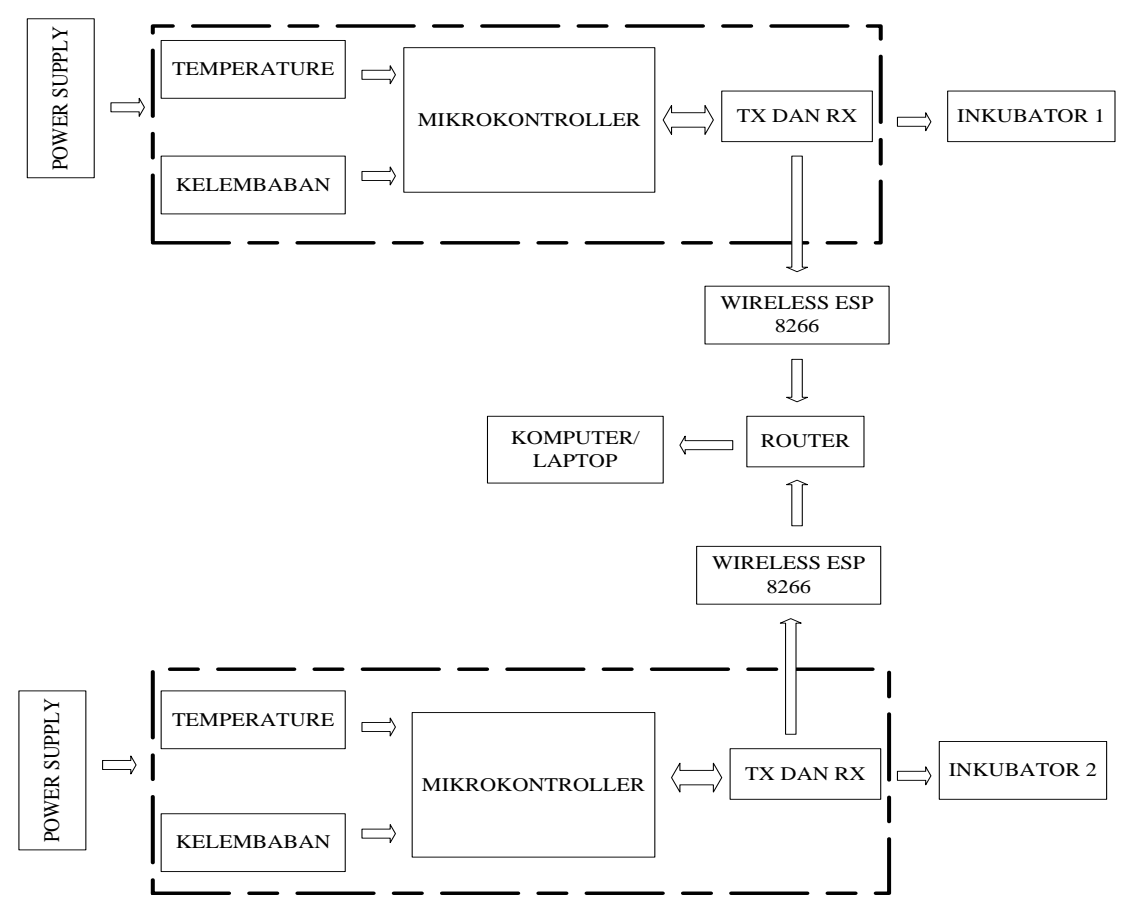

Gambar 1. Diagram Blok Sistem

Pengaturan suhu Baby incubator dapat melalui komputer dan dengan menggunakan tombol yang terdapat di baby incubator. Baby incubator juga dapat di monitoring nilai suhu dan kelembabannya menggunakan komputer, komunikasi komputer dengan baby incubator menggunakan jaringan wirelles sehingga pemantau 2 buah baby incubator dapat di sentralkan atau dapat dimonitoring secara bersamaan. Pada penelitian ini menggunakan 2 buah baby incubator. Sedangkan sistem yang terdapat di masing-masing baby incubator yaitu mengontrol suhu supaya stabil dan mengirimkan hasil pembacaan suhu dan kelembaban ke komputer. Rangakain pengendali heater seperti Gambar 2. Rangkaian Heater dibawah ini : 


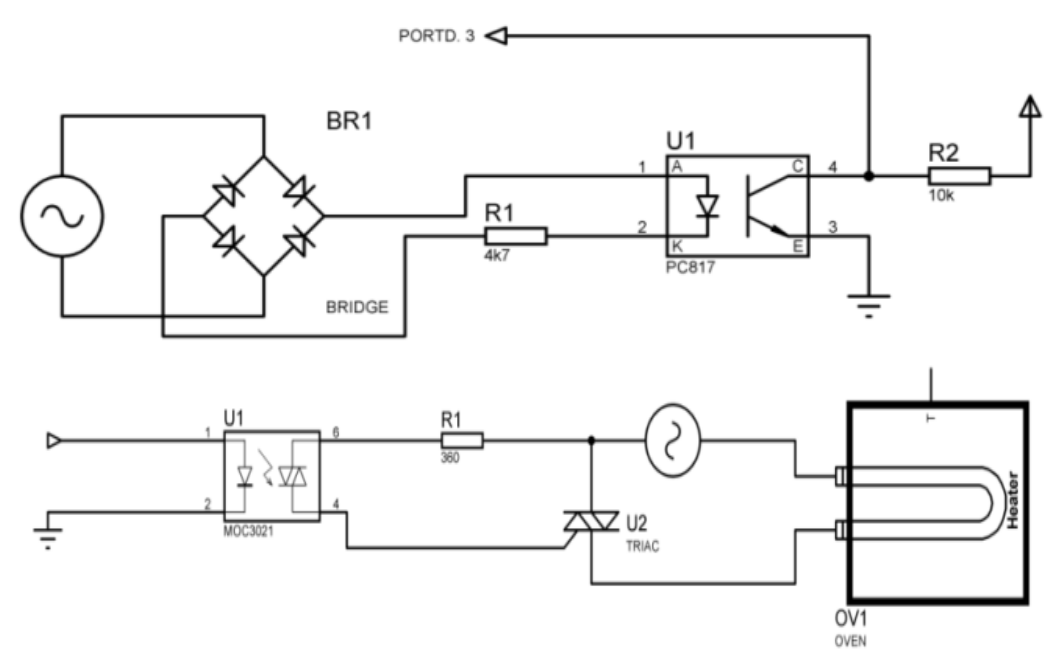

Gambar 2. Rangkaian Heater [3]

Pada rangkaian diatas menggunakan zero crossing detector yang berguna untuk mendeteksi gelombang sinus AC 220 Volt saat melewati titik tegangan nol. Seberangan titik nol yang dideteksi adalah peralihan dari positif menuju negatif dan peralihan dari negatif menuju positif. Seberangan-seberangan titik nol ini merupakan acuan yang digunakan mikrokontroller untuk menentukan berapa daya yang akan diberikan terhadap heater. Besaran daya yang keluar berdasarkan nilai sudut penyalaan yang diatur melalui MOC3022 pada kaki 1. Keluaran dari MOC3022 akan mengatur juga sudut penyaalaan dari triac sehingga panas yang di hasilkan dari heater dapat terkendali. Untuk rangakain pembacaan suhu dan kelembaban yang dihasilkan dari panas heater dengan menggunakan sensor DHT11. Rangkaian seperti Gambar 3. Rangkaian Pembacaan Suhu dan Kelembaban dibawah ini ;

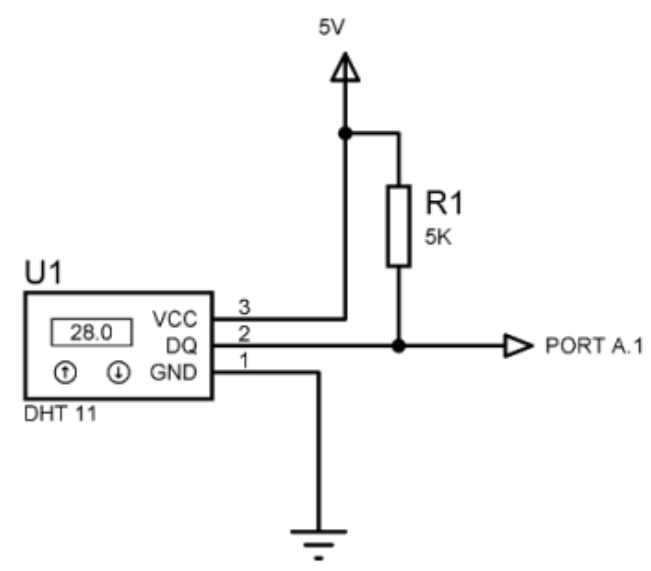

\section{Gambar 3. Rangkaian Pembacaan Suhu dan Kelembaban [5]}

Mikrokontroller menerima data yang dihasilkan dari sensor DH11 ini. Sensor DHT11 dapat membaca nilai suhu dan kelembaban. Tampilan aplikasi pengaturan dan monitoring sentral seperti Gambar 4. Tampilan aplikasi baby incubator sentral dibawah ini; 


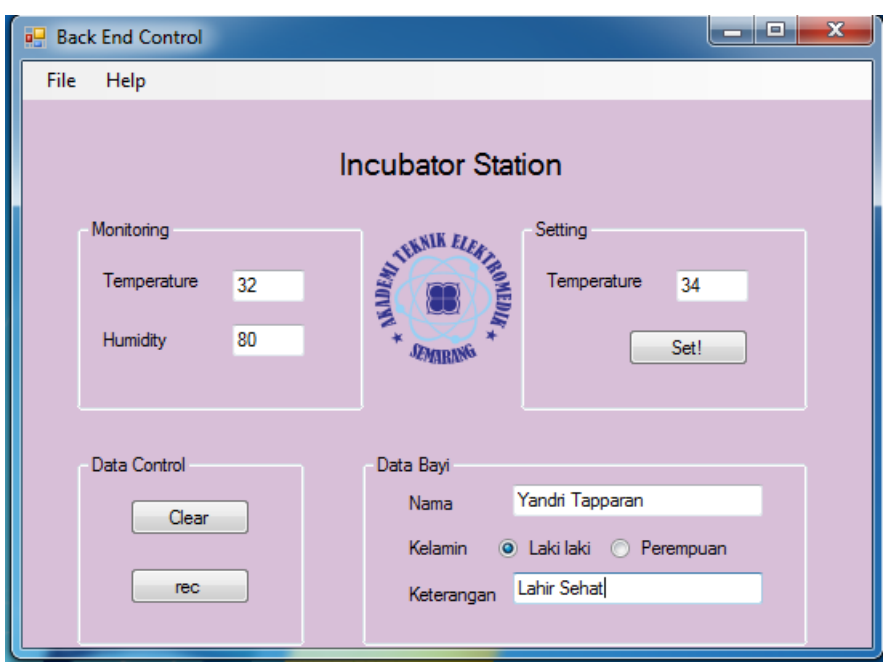

Gambar 4. Tampilan Aplikasi Baby Incubator Sentral

Pada desain tampilan baby incubator sentral terdapat pengaturan suhu, monitoring suhu dan kelembaban dan juga data pasien berupa nama, jenis kelamin dan keterangan kelahiran. Terdapat opsi perekaman data dan hapus data record.

\section{HASIL PENELITIAN DAN PEMBAHASAN}

Pengukuran suhu dan kelembaban ruang baby incubator, pengukuran dilakukan menggunakan termometer ruangan merk GEA kemudian alat diatur suhu $37^{\circ} \mathrm{C}$. Adapun hasil dari pengukuran ini dapat dilihat tabel 1 Pengukuran Suhu dan kelembaban di baby incubator dibawah ini

Tabel 1. Pengukuran Suhu dan kelembaban di baby incubator

\begin{tabular}{lllllll}
\hline No & $\begin{array}{l}\text { Perubahan } \\
\text { Waktu }\end{array}$ & $\begin{array}{l}\text { LM35 } \\
(\boldsymbol{m v})\end{array}$ & $\begin{array}{l}\boldsymbol{L C D} \\
\left({ }^{\boldsymbol{O}} \boldsymbol{C}\right)\end{array}$ & DHT11 & $\begin{array}{l}\text { Termometer } \\
\boldsymbol{G E A}\end{array}$ & \% Kesalahan \\
\hline 1 & 0 & 300,1 & 30,0 & $56 \%$ & 30 & 0 \\
2 & 3,10 & 302,4 & 30,5 & $54 \%$ & 30 & 1,6 \\
3 & 4,10 & 304,5 & 31,2 & $52 \%$ & 31 & 0,6 \\
4 & 20,1 & 368,2 & 37,1 & $43 \%$ & 36 & 3 \\
\hline
\end{tabular}

Berdasarkan tabel diatas, pengukuran suhu dimulai pada suhu $30^{\circ} \mathrm{C}$ dan untuk mencapai suhu $37^{\circ} \mathrm{C}$ memerlukan waktu 20,1 menit.

Pengujian komunikasi baby incubator dengan komputer dilakukan untuk memastikan data yang dikirim dapat dipertanggung jawabkan dan memenuhi quality of service (qos). Pengujian dengan mengunakan device terminal. Tampilan pengujian dapat dilihat pada gambar 5 Tampilan pengiriman data menggunakan device terminal dibawah ini;

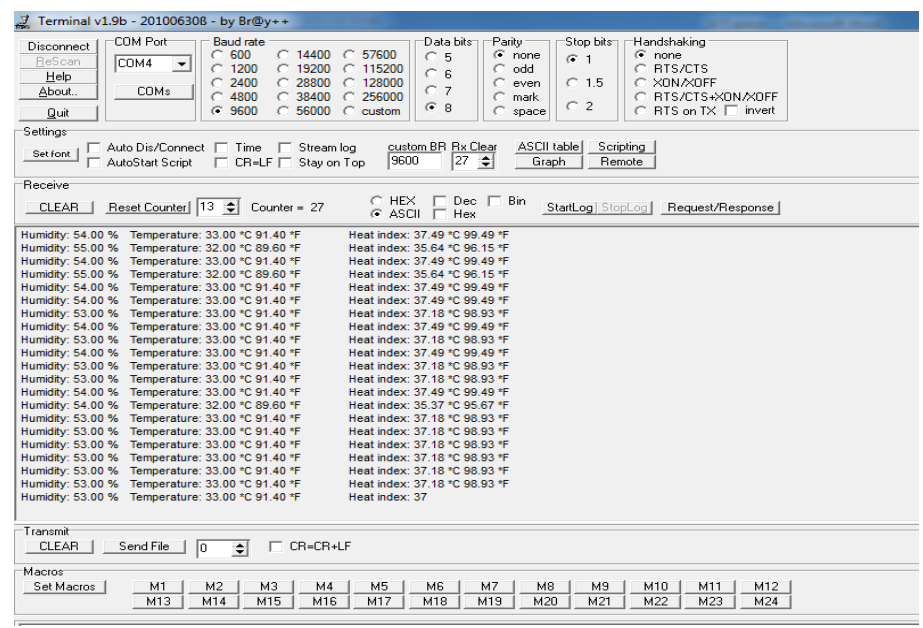

Gambar 5. Tampilan Pengiriman Data Menggunakan Device Terminal 
Pengujian interface melalui front end user inteface. Koneksi login atau pendeteksian antara komputer dengan modul wireless KYL 1020 telah berhasil dengan baik. Koneksi dapat terjadi dengan menyamakan baud rate, memilih konfigurasi port yang dipakai melalui USB to serial. Tampilan pengujian seperti Gambar 6. Tampilan pengujian melalui front end user inteface dibawah ini.

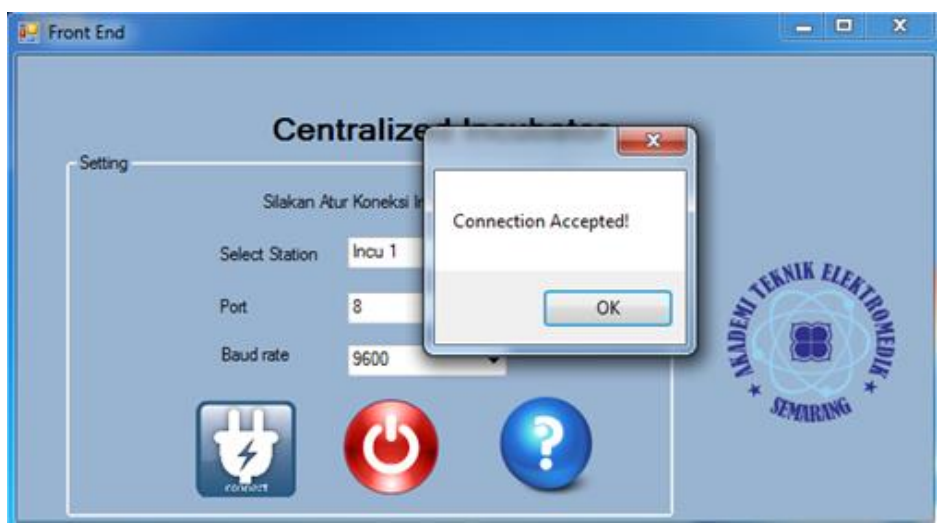

Gambar 6. Tampilan Pengujian Melalui Front End User Inteface

Pengujian pengiriman data kondisi line of sight (LOS) dan Non-Line of sight (NLOS) merupakan pengujian pengiriman data dengan parameter jarak yang bertujuan untuk mengetahui seberapa jauh data dapat dikirim dari $T x$ ke $R x$ tanpa adanya halangan dan dengan adanya penghalang. Setelah pengukuran jarak dilakukan, maka diperoleh data seperti tabel 2 Pengujian jarak koneksi KYL 1020U kondisi LOS dan tabel 3 Pengujian jarak koneksi KYL 1020U kondisi NLOS;

Tabel 2. Pengujian jarak koneksi KYL 1020U kondisi LOS

\begin{tabular}{ccccccccccccccc}
\hline Jarak $(\mathrm{m})$ & 20 & 40 & 60 & 80 & 100 & 120 & 140 & 160 & 180 & 200 & 220 & 230 & 250 \\
\hline Status & C & C & C & C & C & C & C & C & C & C & C & D & D \\
\hline
\end{tabular}

Tabel 3. Pengujian jarak koneksi KYL $1020 \mathrm{U}$ kondisi NLOS

\begin{tabular}{cccccccccccccc}
\hline Jarak $(\mathrm{m})$ & 20 & 40 & $\mathbf{6 0}$ & $\mathbf{8 0}$ & $\mathbf{1 0 0}$ & $\mathbf{1 2 0}$ & $\mathbf{1 4 0}$ & $\mathbf{1 6 0}$ & $\mathbf{1 8 0}$ & $\mathbf{2 0 0}$ & $\mathbf{2 2 0}$ & $\mathbf{2 3 0}$ & $\mathbf{2 5 0}$ \\
\hline Status & $\mathrm{C}$ & $\mathrm{C}$ & $\mathrm{C}$ & $\mathrm{C}$ & $\mathrm{C}$ & $\mathrm{C}$ & $\mathrm{C}$ & $\mathrm{C}$ & $\mathrm{C}$ & $\mathrm{D}$ & $\mathrm{D}$ & $\mathrm{D}$ & $\mathrm{D}$ \\
\hline
\end{tabular}

Dapat dianalisa bahwa saat kondisi $L O S$, jarak terjauh data yang diterima antara baby incubator(Tx) ke komputer $(R x)$ dalam transmisi data sejauh $220 \mathrm{~m}$. Lebih dari 220m, maka data tidak diterima. Pada saat kondisi $N L O S$, jarak terjauh data yang diterima antara baby incubator $(T x)$ ke $\operatorname{komputer}(R x)$ dalam transmisi data sejauh $180 \mathrm{~m}$. Lebih dari $180 \mathrm{~m}$, maka data tidak akan diterima. Perbedaan jarak data yang dapat diterima antara $N L O S$ dan $L O S$ disebabkan faktor penghalang. Apabila ruangan dengan penghalang lebih rapat dapat memungkinkan jarak komunikasi baby incubator dengan kemputer dapat menjadi lebih pendek.

\section{KESIMPULAN}

a. Waktu yang dibutuhkan dalam proses untuk pencapaian suhu $37^{\circ} \mathrm{C}$ mencapai waktu 23,1 menit.

b. Maksimal jarak yang dapat dicapai untuk pengiriman data dalam kondisi line of sight (LOS) adalah $220 \mathrm{~m}$ sedangkan untuk Non-Line of sight (NLOS) adalah $180 \mathrm{~m}$.

c. Komunikasi baby incubator dan komputer sudah terhubung melalui wireless sehingga pengaturan dan monitoring suhu serta kelembaban melalui komputer telah berhasil.

\section{DAFTAR PUSTAKA}

[1] Ginting, Christian F dkk. 2012, Perancangan Incubator Bayi Dengan Pengaturan Suhu dan Kelembaban Berbasis Mikrokontroller ATMega8535. Departemen Fisika, Fakultas MIPA, Universitas Sumatera Utara, Medan.

[2] Syahrul. Pengembangan Inkubator Bayi Dan Sistem Pemantauan Remote. Jurnal Tekno lnsentif Kopwil4, Volume 6, No. 2, oktober 2012. Unikom Bandung. I55N:1907-4964, halaman 9 s.d. 17, 2012.

[3] Roni Wijaya, F dkk. 2013. Inkubator Bayi Berbasis Mikrokontroller Dilengkapi Sistem Telemetri Melalui Jaringan RS-485 . Prodi Teknik Elektro, Fakultas Teknik Elektronika dan Komputer, Universitas Kristen Satya Wacana, Salatiga. 
[4] M. R. APRIYADI. 2012, Miniatur Pemantau Suhu Inkubator Bayi Berbasis Mikrokontroler Atmega 8535 Dan Jaringan Nirkabel. Jakarta, 2012.

[5] Noor Yulita Dwi Setyaningsih dkk. 2016, Kendali Suhu Inkubator Bayi Menggunakan PID, Jurnal SIMETRIS, Vol 7 No 2 November 2016 ISSN: 2252-4983. 